\title{
Myometrial Angiotensin II Receptor Subtypes Change during Ovine Pregnancy
}

\author{
B. E. Cox, M. A. Ipson, P. W. Shaul, K. E. Kamm, and C. R. Rosenfeld \\ Departments of Pediatrics and Physiology, The University of Texas Southwestern Medical Center at Dallas, Dallas, Texas 75235
}

\begin{abstract}
Although regulation of angiotensin II receptor (AT) binding in vascular and uterine smooth muscle is similar in nonpregnant animals, studies suggest it may differ during pregnancy. We, therefore, examined binding characteristics of myometrial AT receptors in nulliparous $(n=7)$, pregnant $(n=24,110-139$ d of gestation $)$, and postpartum $(n=21,5$ to $\geq 130 \mathrm{~d})$ sheep and compared this to vascular receptor binding. We also determined if changes in myometrial binding reflect alterations in receptor subtype. By using plasma membrane preparations from myometrium and medial layer of abdominal aorta, we determined receptor density and affinity employing radioligand binding; myometrial AT receptor subtypes were assessed by inhibiting [ $\left.{ }^{125} \mathrm{I}\right]$-ANG II binding with subtype-specific antagonists. Compared to nulliparous ewes, myometrial AT receptor density fell $\sim 90 \%$ during pregnancy $(1,486 \pm 167$ vs. $130 \pm 16$ $\mathrm{fmol} / \mathrm{mg}$ protein) and returned to nulliparous values $\geq 4$ wk postpartum; vascular binding was unchanged. Nulliparous myometrium expressed predominantly $\mathrm{AT}_{2}$ receptors $\left(\mathrm{AT}_{1} /\right.$ $\mathrm{AT}_{2} \simeq 15 \% / 85 \%$ ), whereas $\mathrm{AT}_{1}$ receptors predominated during pregnancy $\left(\mathrm{AT}_{1} / \mathrm{AT}_{2} \simeq 80 \% / 20 \%\right)$. By 5 d postpartum $\mathrm{AT}_{1} / \mathrm{AT}_{2} \simeq 40 \% / 60 \%$, and $>4$ wk postpartum $\mathrm{AT}_{2}$ receptors again predominated $\left(\mathrm{AT}_{1} / \mathrm{AT}_{2} \simeq 15 \% / 85 \%\right)$. In studies of ANG II-induced force generation, myometrium from pregnant ewes $(n=10)$ demonstrated dose-dependent increases in force $(P<0.001)$, which were inhibited with an $\mathrm{AT}_{1}$ receptor antagonist. Postpartum myometrial responses were less at doses $\geq 10^{-9} \mathrm{M}(P<0.05)$ and unaffected by $\mathrm{AT}_{2}$ receptor antagonists. Vascular and myometrial AT receptor binding are differentially regulated during ovine pregnancy, the latter primarily reflecting decreases in $\mathrm{AT}_{2}$ receptor expression. This is the first description of reversible changes in AT receptor subtype in adult mammals. (J. Clin. Invest. 1993. 92:2240-2248.) Key words: force generation • puerperium • uterus • vascular smooth muscle
\end{abstract}

\section{Introduction}

Normal pregnancy is characterized by a variety of hormonal and cardiovascular changes, including decreases in systemic vascular resistance, increases in cardiac output, development

This paper was presented in part at the FASEB Annual Meeting, Anaheim, CA, April 1992.

Address reprint requests to Dr. Charles R. Rosenfeld, Department of Pediatrics, University of Texas Southwestern Medical Center at Dallas, Dallas, TX 75235-9063.

Received for publication 22 October 1992 and in revised form 21 June 1993

J. Clin. Invest.

(c) The American Society for Clinical Investigation, Inc.

0021-9738/93/11/2240/09 \$2.00

Volume 92, November 1993, 2240-2248 of the uteroplacental vascular bed, and enhanced activation of the renin-angiotensin system, which results in increased levels of plasma renin activity and angiotensin II (ANG II) ${ }^{1}$ (1). Pregnant women also develop refractoriness to the systemic pressor effects of infused ANG II (2-4); that is, the dose of ANG II necessary to elicit a $20-\mathrm{mmHg}$ rise in blood pressure is greater in normotensive pregnant women as compared to nonpregnant women. In contrast, pregnant women destined to develop preeclampsia lose this refractoriness and become increasingly sensitive to the pressor effects of infused ANG II (4); however, the mechanism(s) responsible for these changes is unknown. The pregnant ewe $(5,6)$ and several other species $(7$, 8) also develop attenuated pressor responses to infused ANG II. Moreover, the dose of ANG II required to elicit a $20-\mathrm{mmHg}$ rise in mean arterial pressure in pregnant and nonpregnant ewes is virtually identical to that required in normotensive pregnant and nonpregnant women, respectively (3-5). The pregnant ewe and women share other similarities in cardiovascular adaptation (9-11); therefore, the ewe is an excellent model in which to study the cardiovascular changes associated with normal pregnancy, including the refractoriness to infused ANG II.

In the pregnant ewe as in women, the attenuated pressor responses to ANG II occur in association with substantial increases in plasma renin activity and circulating ANG II (1113). In nonpregnant adult animals increases in circulating ANG II result in a decrease in the density of ANG II receptors (AT) in vascular (14-17) and nonvascular (16-20) smooth muscle, including uterine smooth muscle (i.e., myometrium). Thus, the attenuated pressor responses to infused ANG II seen in pregnancy may simply reflect downregulation of the vascular smooth muscle AT receptor. This, however, is not supported by indirect studies in women $(21,22)$ and sheep (11), as well as more recent studies of ANG II binding characteristics in arteries from pregnant animals $(12,23)$. In these studies there was no difference in either total AT receptor binding density or affinity in the aorta, mesenteric artery, or uterine artery of pregnant and nonpregnant ewes (12) or the mesenteric artery of pregnant rats (23). However, several investigators have reported a fall in total AT receptor binding density in myometrium from pregnant sheep (24), rats (25) and rabbits (26). These observations suggest that regulation of the AT receptor may differ between vascular and nonvascular smooth muscle (e.g., myometrium) in response to pregnancy. This, however, has not been studied. Therefore, the objectives of the present studies were $(a)$ to determine the ontogeny of binding characteristics of ovine myometrial AT receptors prior to, during and after pregnancy and to compare these to vascular smooth muscle, and if the myometrial AT receptor is regulated differently, $(b)$ to determine whether this is associated with changes in the expression of receptor subtypes in myometrium and if such changes would be reflected in ANG II-induced force generation.

1. Abbreviations used in this paper: ANG II, angiotensin II; AT, ANG II receptor; PSS, physiologic saline solution. 


\section{Methods}

Tissue preparation. Binding characteristics of vascular and uterine smooth muscle AT were determined in tissues obtained from pregnant ewes at three periods late in gestation (term $145 \pm 4 \mathrm{~d}): 110-120 \mathrm{~d}(n$ $=3), 121-130 \mathrm{~d}(n=5)$, and $131-135 \mathrm{~d}(n=5)$. Tissues also were obtained from early postpartum ewes between 7 and $16 \mathrm{~d}$ after delivery $(n=7)$ and late postpartum ewes from 31 to $130 \mathrm{~d}$ after delivery $(n$ $=5$ ). Uteri from three nulliparous ewes also were studied. Studies of myometrial AT receptor subtypes were determined in tissue obtained from additional pregnant ewes $(n=11)$ between 113 and $139 \mathrm{~d}$ of gestation, early postpartum sheep ( $n=2 ; 5 \mathrm{~d}$ after delivery), late postpartum ewes ( $n=7 ; 18$ to $>108 \mathrm{~d}$ after delivery), and nulliparous sheep $(n=4)$. Animals were killed by i.v. bolus infusion of pentobarbital sodium $(50 \mathrm{mg} / \mathrm{kg}$ ). The abdominal aorta was rapidly removed as was a section of uterus from the middle third of a uterine horn in an area free of encompassing vascular arcades. The tissues were immediately placed in ice-cold $8 \mathrm{mM}$ phosphate-buffered saline ( $\mathrm{pH} \mathrm{7.4)}$ ). After removing residual blood, $100 \mu \mathrm{l}$ of the protease inhibitor PMSF $(0.5 \mathrm{mM})$ was added to the buffer. Fat, connective tissue, and adventitia were dissected from the aorta, and the endothelium was gently removed with a cotton-tipped applicator. The aorta was examined by light microscopy before and after swabbing to verify removal of the endothelium. The remaining medial layer was the source of vascular smooth muscle used in the plasma membrane preparations. The myometrium was quickly dissected free of endometrium as previously reported (27), and the remaining smooth muscle was used in the membrane preparation. These studies were approved by the Institutional Review Board for Animal Research.

Membrane preparation. The smooth muscle specimens $(0.5-1.5 \mathrm{~g})$ were minced in $20 \mathrm{ml}$ of fresh $8 \mathrm{mM}$ phosphate-buffered saline to which $100 \mu \mathrm{l}$ of each of the protease inhibitors PMSF $(0.5 \mathrm{mM})$, leupeptin $(5 \mu \mathrm{g} / \mathrm{ml})$, and aprotinin $(5 \mu \mathrm{g} / \mathrm{ml})$ were added. The minced tissues were transferred into ice-cold $0.25 \mathrm{M}$ sucrose buffer with $25 \mathrm{mM}$

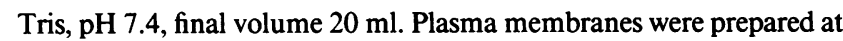
$4^{\circ} \mathrm{C}$ using methods recently described (12). The tissues were homogenized three times for $10 \mathrm{~s}$ using a Polytron (PT-20 probe, Brinkmann Instruments, Inc., Westbury, NY), allowing the probe to cool between homogenizations. The protease inhibitors PMSF, leupeptin, and aprotinin were then added to the homogenate ( $100 \mu$ l of each), which was centrifuged at $10,000 \mathrm{~g}$ for $30 \mathrm{~min}$ at $4^{\circ} \mathrm{C}$. The supernatant was removed and filtered through two layers of gauze, and centrifuged at $45,000 \mathrm{~g}$ for $30 \mathrm{~min}$ at $4^{\circ} \mathrm{C}$. The resulting pellets were resuspended in 5 $\mathrm{ml}$ of $0.6 \mathrm{M} \mathrm{KCl}, 30 \mathrm{mM}$ histidine buffer $(\mathrm{pH} 7.0)$ to solubilize actin and myosin and were recentrifuged at $45,000 \mathrm{~g}$ for $30 \mathrm{~min}$ at $4^{\circ} \mathrm{C}$. The final pellets were resuspended in $25 \mathrm{mM}$ Tris buffer ( $\mathrm{pH} 7.4$ ) containing $10 \mathrm{mM} \mathrm{MgCl}, 10 \mu \mathrm{g} / \mathrm{ml}$ bacitracin, and $0.2 \% \mathrm{BSA}$. The final protein concentration ranged from 22 to $98 \mu \mathrm{g} / 100 \mu \mathrm{l}$ for aorta and from 58 to $200 \mu \mathrm{g} / 100 \mu \mathrm{l}$ for myometrium as determined by a modification of the methods of Lowry et al. (28).

Radioligand binding studies. Radioligand receptor binding experiments were performed at the same time on aorta and myometrium obtained from each animal; all determinations were performed in duplicate. Receptor binding assays were performed with $100 \mu \mathrm{l}$ of fresh membrane preparation in a total volume of $150 \mu$ of the $25 \mathrm{mM}$ Tris buffer with $0.2 \%$ BSA. Tyrosyl ${ }^{125} \mathrm{I}$-[ 5 -L-isoleucine]-ANG II $\left(\left[{ }^{125} \mathrm{I}\right]\right.$ ANG II, 2,200 Ci/mmol; New England Nuclear, Boston, MA) was added in concentrations from 0.3 to $0.4 \mathrm{nM}$. Unlabeled ANG II was added in increasing concentrations ranging from $10^{-11}$ to $10^{-8} \mathrm{M}$, and the binding characteristics were determined from analysis of the displacement of labeled ligand. ANG II at $10^{-5} \mathrm{M}$ concentration was used to determine nonspecific binding. In previous studies specific binding of [ $\left.{ }^{125} \mathrm{I}\right]$-ANG II reached equilibrium by $60 \mathrm{~min}$ of incubation for aorta (12). Equilibrium was reached by $90 \mathrm{~min}$ for myometrium; therefore, 90 -min incubations were used in all binding studies. Linearity of specific radioligand binding versus the amount of membrane protein incubated has been confirmed previously for aorta (12) and also was confirmed for myometrium.
Competitive binding studies were performed with $10^{-11}$ to $10^{-5} \mathrm{M}$ unlabeled ANG II, ANG III, [ $\mathrm{Sar}^{1}, \mathrm{Val}^{5}, \mathrm{Ala}^{8}$ ]-ANG II, and $10^{-11}$ to $10^{-4} \mathrm{M}$ ANG I and arginine vasopressin (AVP; Sigma Chemical Co., St. Louis, MO.). All incubations were performed at $18^{\circ} \mathrm{C}$ and were terminated by rapid addition of $4 \mathrm{ml}$ of ice-cold $25 \mathrm{mM}$ Tris buffer with $0.2 \%$ BSA. Bound and free ligand were separated by filtration through Whatman GF/C filters (Whatman International Ltd, Maidstone, UK) under vacuum followed by three rinses of the filters with the buffer. After the filters were dry, the radioactivity was measured using a scintillation counter (Packard Instruments, Inc., Downers Grove, IL) with $71 \%$ efficiency. The density $\left(B_{\max }\right)$ of smooth muscle receptors in femtomoles per milligram of protein and the dissociation constants $\left(K_{\mathrm{d}}\right.$, $\mathrm{nM}$ ) were calculated from the specific binding data using a modification of the computer program LIGAND (29) adapted for microcomputers by McPherson (Elsevier BIOSOFT, Cambridge, UK) (30).

Receptor subtype characterization. To determine the AT receptor subtypes, competitive binding studies were performed with $10^{-11}$ to $10^{-5} \mathrm{M}$ unlabeled $\left[\mathrm{Sar}^{1}, \mathrm{Ile}^{8}\right.$ ]-ANG II and the subtype-specific antagonists DuP753 (Losartan; The DuPont Merck Pharmaceutical Co., Wilmington, DE), PD123177 (Parke-Davis Pharmaceutical, Ann Arbor, MI), and CGP42112A (Ciba-Geigy Ltd., Basel, Switzerland). Losar$\tan$ displaces the $\mathrm{AT}_{1}$ receptor subtype and $\mathrm{PD} 123177$ and CGP42112A are specific for the $\mathrm{AT}_{2}$ receptor subtype. Specific binding was calculated by subtracting nonspecific binding, measured in the presence of $10^{-5} \mathrm{M}$ [ $\mathrm{Sar}^{1}, \mathrm{Ile}^{8}$ ]-ANG II, from total [ ${ }^{125} \mathrm{I}$ ]-ANG II binding. The percentages of the two receptor subtypes were extrapolated from the percentage of inhibition observed when the specific binding displacement curves were compared (31). Additional plasma membrane preparations made from pregnant and postpartum myometrium were preincubated with $10^{-6} \mathrm{M}$ Losartan or either PD123177 or CGP42112A, respectively. This concentration is sufficient to saturate the respective subtype without affecting the alternate subtype. With the predominant receptor subtype blocked, competitive binding studies were performed to confirm the presence of the alternate population of subtype. A further estimation of the percent concentration of receptor subtypes was determined by subtracting the binding in the presence of $10^{-6} \mathrm{M}$ concentration of the respective subtype-selective antagonist from specific binding (32).

Force generation studies. Samples of myometrium obtained from the dorsal area of one uterine horn from pregnant ( $n=10,85-140 \mathrm{~d})$ and postpartum ( $n=16,5-42 \mathrm{~d}$ after delivery) ewes were placed in physiologic saline solution (PSS) containing (in $\mathrm{mM}$ ): $120.5 \mathrm{NaCl}, 4.8$ $\mathrm{KCl}, 1.2 \mathrm{MgSO}_{4}, 1.2 \mathrm{NaH}_{2} \mathrm{PO}_{4}, 20.4 \mathrm{NaHCO}_{3}, 1.6 \mathrm{CaCl}_{2}, 10$ dextrose, and 1 pyruvate. The endometrium was removed, and myometrial strips of $\sim 1 \times 0.2 \times 0.2 \mathrm{~cm}$ were cut with a double-bladed cutting tool in the longitudinal direction with respect to the long axis of the uterine horn. Strips were tied at both ends with 4-0 silk; the bottom tie was hooked to a stainless steel rod attached to a mechanical drive used to adjust muscle length and the top to a model FT.03C force transducer (Grass Instrument Co., Chauncey, MA). Force was recorded on a Grass model 7D polygraph. The strips were suspended in a $25-\mathrm{ml}$ jacketed organ bath maintained at $37^{\circ} \mathrm{C}$. PSS was bubbled with $95 \% \mathrm{O}_{2}$ and $5 \% \mathrm{CO}_{2}$ to maintain a pH of 7.4. Strips were stretched to $70-80 \%$ of optimal length according to previously determined length-force relations (33). Tissues were stimulated with $65 \mathrm{mM} \mathrm{KCl}(\mathrm{KCl}$ isotonically replaced $\mathrm{NaCl}$ in PSS) then washed with PSS and allowed to equilibrate for $1 \mathrm{~h}$ or until regular spontaneous activity was observed. One strip from each animal was used as a control; the remaining strips were stimulated with increasing concentrations of ANG II (Ciba Geigy, Summit, NJ) ranging from $10^{-11}$ to $10^{-6} \mathrm{M}$ for $10 \mathrm{~min}$ and then washed with PSS and allowed to reequilibrate for $20 \mathrm{~min}$. The area under the force trace for each concentration was measured for $10 \mathrm{~min}$ before and $10 \mathrm{~min}$ after the application of each dose of ANG II using the JAVA program (Jandel Scientific Computer Corp., Corte Madera, CA). Force tracings obtained for 10 min before ANG II exposure were used as the baseline activity. These values were subtracted from the responses to each dose of ANG II over $10 \mathrm{~min}$ in order to determine the actual effect of ANG II on integrated myometrial force generation ex- 
pressed as dynes per $10 \mathrm{~min}$. In selected studies of myometrial strips from pregnant and postpartum ewes $10^{-6}$ or $10^{-5} \mathrm{M}$ Losartan was added to the tissue bathing solution before addition of $10^{-7} \mathrm{M}$ ANG II. In other studies $10^{-5} \mathrm{M}$ PD123177 was added to baths of myometrial strips from early and late postpartum ewes $30 \mathrm{~min}$ after the last ANG II concentration response, measuring the response to a repeat dose of $10^{-7} \mathrm{M}$ ANG II 4 min later. Forces were normalized to the maximum contractile response obtained with a mixture of stimulating agents containing $65 \mathrm{mM} \mathrm{KCl}, 5 \mathrm{mM} \mathrm{CaCl}_{2}, 100 \mu \mathrm{M}$ carbachol, and $1 \mathrm{mU} / \mathrm{ml}$ oxytocin.

Statistical methods. Alterations in binding characteristics across gestation and the puerperium for aortic smooth muscle and myometrium were compared using analysis of variance (ANOVA) followed by Neuman-Keuls test for multiple comparisons. This was also used to evaluate myometrial force generation in pregnant and postpartum tissues. Welch's nonparametric analysis was used, when indicated, to compare groups with small sample size. Matched data were compared using Student's $t$ test. Linear correlation analysis was used to evaluate the relationships between $B_{\max }$ and $K_{\mathrm{d}}$ and gestational/postpartum age. In addition, an exponential relationship $\left(y=e^{b+a}\right.$ age $)$ between $B_{\max }$ and gestational/postpartum age was also examined using nonlinear regression analysis. All data are presented as the mean \pm 1 SEM. Statistical significance was accepted at $P<0.05$.

\section{Results}

Angiotensin II receptors. LIGAND analysis of the displacement of [ $\left.{ }^{125} \mathrm{I}\right]-\mathrm{ANG}$ II by unlabeled ANG II demonstrated one-site

\section{A. Myometrium}
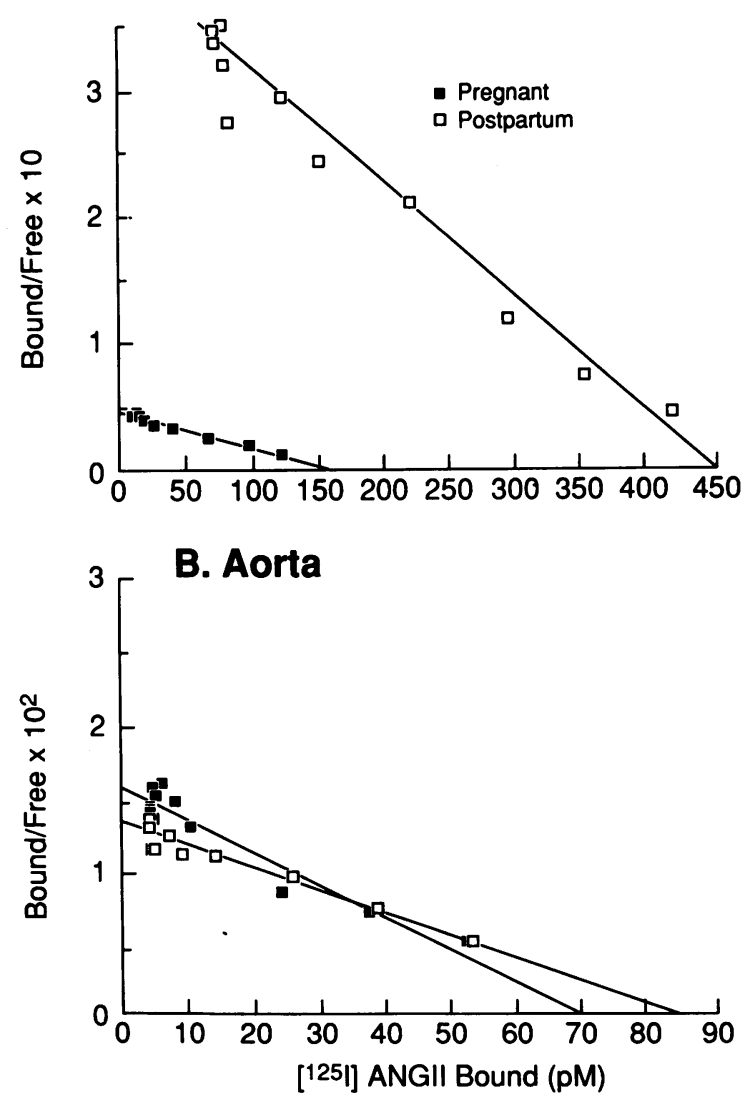

Figure 1. Representative Scatchard plots of [ $\left.{ }^{125} \mathrm{I}\right]-\mathrm{ANG}$ II binding to plasma membrane fractions prepared from $(A)$ myometrium and $(B)$ aorta from pregnant and postpartum ewes. The ratio of bound to free $\left[{ }^{125} \mathrm{I}\right]-A N G$ II is plotted as a function of specifically bound $\left[{ }^{125} \mathrm{I}\right]$-ANG II. Each point was determined in duplicate.

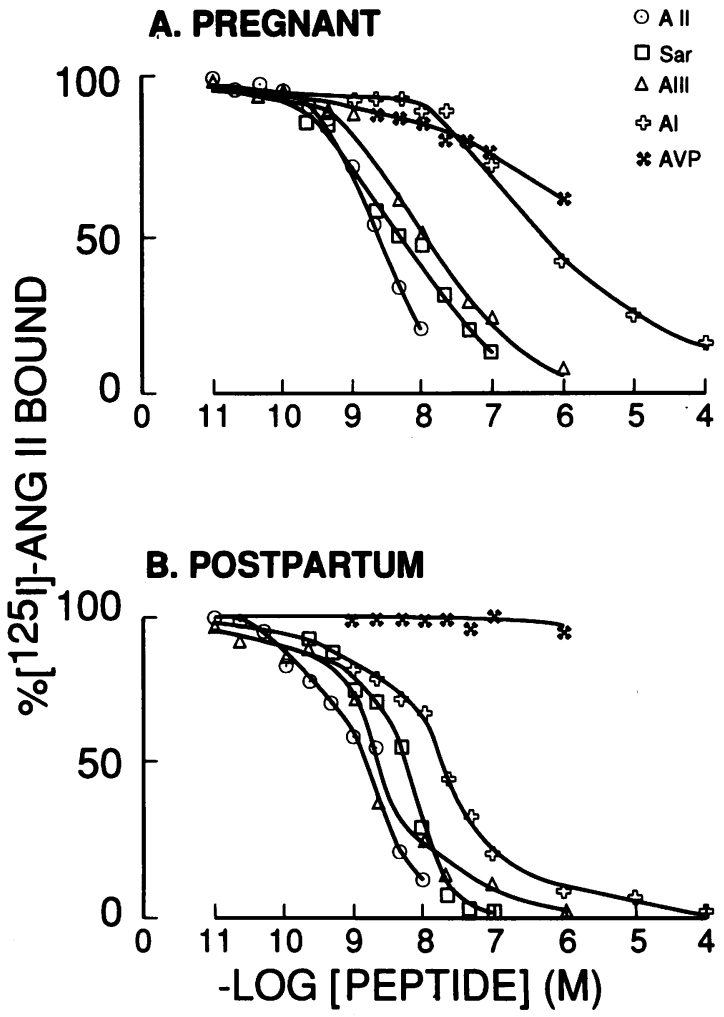

Figure 2. Displacement curves for [ $\left.{ }^{125} \mathrm{I}\right]-\mathrm{ANG}$ II binding to plasma membrane fractions prepared from ovine myometrium obtained during $(A)$ pregnancy and the $(B)$ puerperium. Values are the mean of three experiments with each peptide, each performed in duplicate. Sar represents $\left[\mathrm{Sar}^{1}, \mathrm{Val}^{5}, \mathrm{Ala}^{8}\right]-A N G$ II.

models for both vascular $(P<0.05, r>0.90)$ and myometrial $(P<0.05, r>0.95)$ receptors, each having a single class of high-affinity saturable binding sites. Representative Scatchard plots of specific binding data for membrane fractions prepared from myometrium and aorta obtained from pregnant and postpartum ewes are illustrated in Fig. 1. The slopes for pregnant and postpartum aorta are similar and comparable to that generated for pregnant myometrium. In contrast, the slope representing postpartum myometrium is significantly greater $(P$ $<0.03$ ), reflecting a lower $K_{\mathrm{d}}$.

Specific binding at $K_{\mathrm{d}}$ for vascular and myometrial AT receptors was generally $>75 \%$ and $>85 \%$, respectively. The majority of nonspecific binding was accounted for by binding of the radioligand to the GF/C filters. This was not altered by prewetting the filters with albumin-containing buffer. Hill coefficients ranged from 0.96 to 1.03 and from 0.78 to 1.32 for vascular and myometrial preparations, respectively, indicating that cooperativity was not involved in the binding of $\left[{ }^{125} \mathrm{I}\right]$ ANG II to the smooth muscle receptors (34).

The ability of several ANG II analogues and the unrelated peptide hormone AVP to displace [ ${ }^{125}$ I]-ANG II binding to plasma membrane fractions prepared from ovine myometrium obtained during pregnancy and the postpartum period are seen in Fig. 2. The orders of potency identified in myometrium from pregnant and postpartum ewes were: ANG II $\geq$ SAR $>$ ANG III $>$ ANG I and ANG II $\geq$ ANG III $>$ SAR $>$ ANG I, respectively. AVP did not displace [ $\left.{ }^{125} \mathrm{I}\right]$-ANG II in either pregnant or postpartum myometrium except at concentrations $\geq 10^{-6} \mathrm{M}$ (data not shown), likely representing nonspecific 
binding or contamination with ANG II analogues which have not been identified. These findings are characteristic of binding to AT receptors $(14,17,18,24)$. Data for aorta (not shown) were similar to those previously reported (12).

When we examined total AT receptor binding density in myometrium from nulliparous ewes, animals never having been pregnant, values averaged $1486 \pm 167 \mathrm{fmol} / \mathrm{mg}$ protein (Fig. 3). This is significantly greater $(P<0.001)$ than that seen in myometrium obtained between 110 and $135 \mathrm{~d}$ of pregnancy, during which time total binding density was unchanged and averaged $130 \pm 16 \mathrm{fmol} / \mathrm{mg}$ protein (Fig. $3 \mathrm{~A}$ ). After parturition, binding density increased gradually and tissues obtained $>4$ wk postpartum had an average binding density 14-fold greater than that seen at 131-135 d of pregnancy $(1,403 \pm 321$ vs. $101 \pm 13 \mathrm{fmol} / \mathrm{mg}$ protein, $P<0.001$, respectively), but not different from that observed in myometrium from nulliparous ewes. The pattern of the rise in total myometrial receptor density after parturition is best described by an exponential relationship $(P<0.001, r=0.78)$. In contrast, total AT receptor binding density in pregnant and postpartum vascular smooth muscle did not differ (Fig. $3 \mathrm{~B}$ ). Although the vascular and myometrial $B_{\max }$ were similar during the last third of gestation studied, after $4 \mathrm{wk}$ postpartum values were greater in myometrium, $P<0.001$.

The dissociation constant in myometrium from nulliparous ewes averaged $2.77 \pm 0.58 \mathrm{nM}$, a value nearly half that seen in myometrium obtained before $130 \mathrm{~d}$ of gestation (Fig. $4 \mathrm{~A}$,

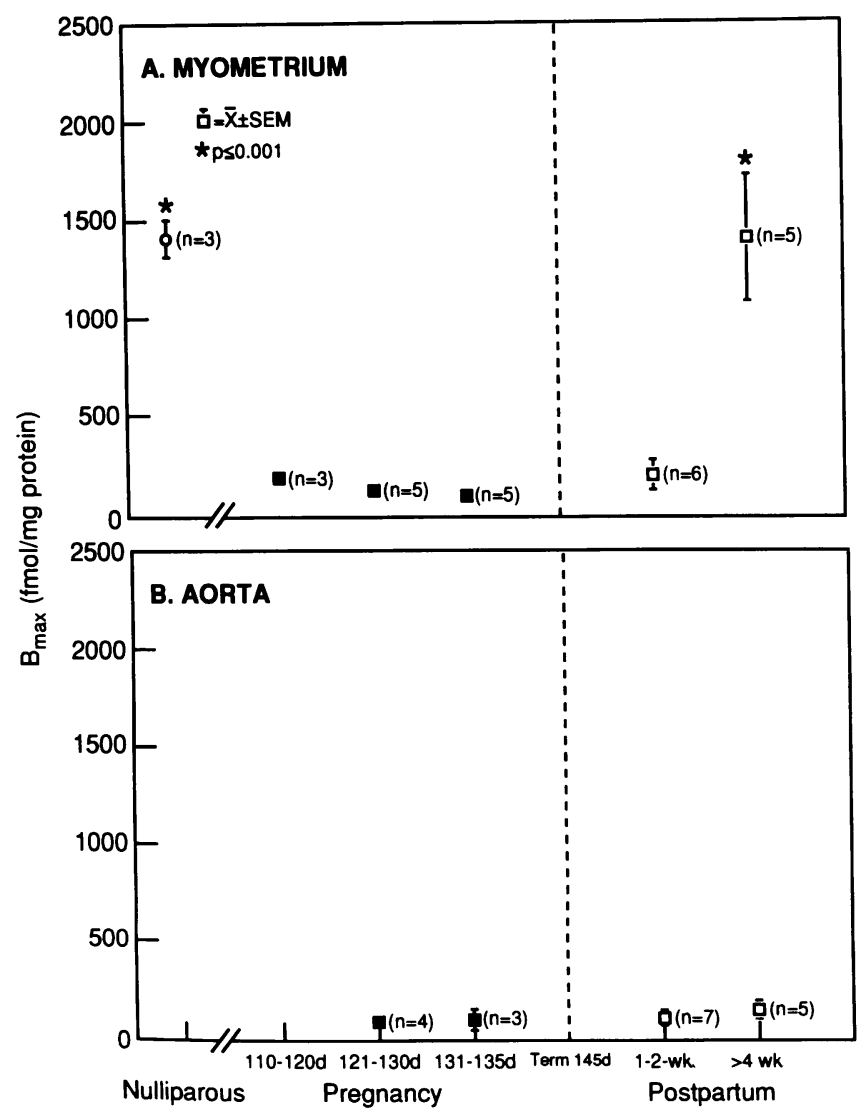

Figure 3. Total angiotensin II receptor binding density $\left(B_{\max }\right)$ during ovine pregnancy and the puerperium in $(A)$ myometrium and $(B)$ aortic smooth muscle. ${ }^{*} P \leq 0.001$ as compared to values during pregnancy.

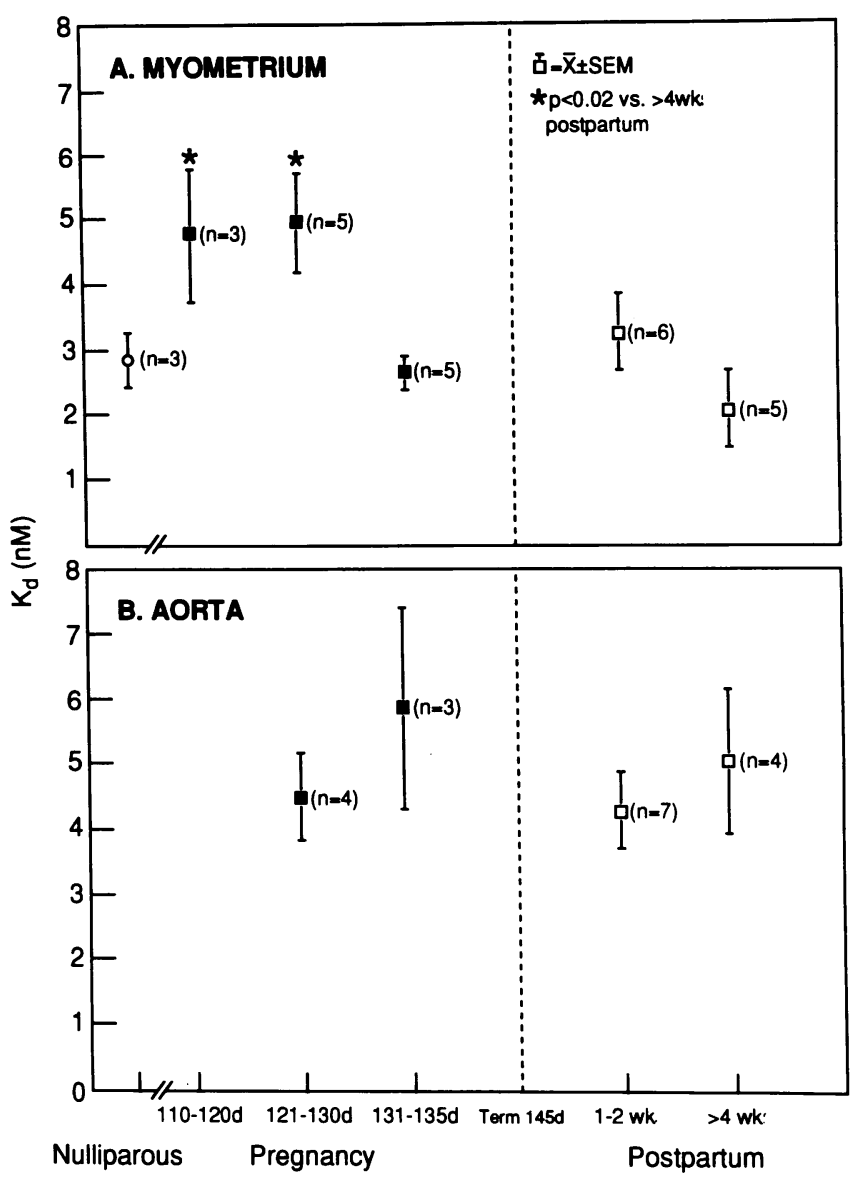

Figure 4. Angiotensin II receptor binding affinity $\left(K_{\mathrm{d}}\right)$ during pregnancy and the puerperium in $(A)$ myometrium and $(B)$ aortic smooth muscle.

$4.90 \pm 0.57, P=0.06$. While myometrial AT receptor $B_{\max }$ was unchanged during the last third of gestation, the binding affinity increased nearly twofold during the last $2 \mathrm{wk}$ of pregnancy (Fig. $4 A$ ), the $K_{\mathrm{d}}$ decreasing from $4.97 \pm 0.46 \mathrm{nM}$ at $121-130 \mathrm{~d}$ to $2.66 \pm 0.25 \mathrm{nM}$ at $131-135 \mathrm{~d}(P<0.05)$. Values in myometrium from postpartum animals were similar to that seen in the last $2 \mathrm{wk}$ of pregnancy and in nulliparous tissues, $2.75 \pm 0.44 \mathrm{vs}$. $2.77 \pm 0.58 \mathrm{nM}$, respectively. The fall in $K_{\mathrm{d}}$ correlated with advancing gestational and postpartum age $(P<0.05, r=-0.42)$. As previously reported (12), aortic $K_{\mathrm{d}}$ was unchanged throughout ovine pregnancy and the puerperium (Fig. $4 \mathrm{~B}$ ), averaging $5.00 \pm 0.73 \mathrm{nM}$. Values for aortic smooth muscle $K_{\mathrm{d}}$ are significantly greater $(P<0.001)$ than that for myometrium after 130 $\mathrm{d}$ of gestation and throughout the puerperium, averaging $2.72 \pm 0.32 \mathrm{nM}$.

$A T$ receptor subtypes. To determine if the pregnancy-related alterations in myometrial binding characteristics reflect a change in AT receptor subtype, we examined the inhibition of $\left[{ }^{125} \mathrm{I}\right]-\mathrm{ANG}$ II binding by subtype specific receptor antagonists (Table I, Fig. 5). Experiments were performed in duplicate with each antagonist at each time period studied. $\mathrm{IC}_{50}$ values for $\left[\mathrm{Sar}^{1}, \mathrm{Ile}^{8}\right]$-ANG II, which has equal affinity for both re-

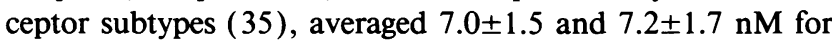
pregnant and postpartum myometrium, respectively. LIGAND analysis of the displacement of $\left[{ }^{125} \mathrm{I}\right]-\mathrm{ANG}$ II by [ $\left.\mathrm{Sar}^{1}, \mathrm{Ile}^{8}\right]$ ANG II was used to determine $100 \%$ binding of myometrial AT receptor subtypes. 
Table I. Characterization of Myometrial Angiotensin Receptor Subtypes before, during, and after Ovine Pregnancy as Determined by Inhibition of $\left[{ }^{125} I\right]-A N G$ II Binding with Receptor Subtype-specific Antagonists

\begin{tabular}{|c|c|c|c|c|}
\hline & \multicolumn{4}{|c|}{$\mathrm{IC}_{50}$} \\
\hline & $\left.\operatorname{Sar}^{1} \mathrm{Ile}^{\mathrm{s}}\right]$-ANG II & Losartan & PD123177 & CGP42112A \\
\hline & \multicolumn{4}{|c|}{$n M$} \\
\hline Nulliparous & $\begin{array}{c}12.6 \pm 5.7 \\
(n=2)\end{array}$ & $\begin{array}{c}>100,000 \\
(n=2)\end{array}$ & $\begin{array}{c}18.6 \pm 3.8 \\
(n=2)\end{array}$ & NA \\
\hline \multicolumn{5}{|l|}{ Pregnant } \\
\hline $112-119 d$ & $\begin{array}{l}7.7 \pm 3.4 \\
(n=3)\end{array}$ & $\begin{array}{c}62 \pm 11 \\
(n=3)\end{array}$ & $\begin{array}{c}>100,000 \\
(n=3)\end{array}$ & $\begin{array}{c}>100,000 \\
(n=2)\end{array}$ \\
\hline$\geq 130 \mathrm{~d}$ & $\begin{array}{l}4.2 \pm 1.4 \\
(n=5)\end{array}$ & $\begin{array}{l}103 \pm 60 \\
(n=5)\end{array}$ & $\begin{array}{c}>100,000 \\
(n=5)\end{array}$ & $\begin{array}{c}>100,000 \\
(n=3)\end{array}$ \\
\hline \multicolumn{5}{|l|}{ Postpartum } \\
\hline $5 \mathrm{~d}$ & $\begin{array}{c}11.0 \pm 2.4 \\
(n=2)\end{array}$ & $\begin{array}{r}99 \pm 57 \\
(n=2)\end{array}$ & $\begin{array}{l}7.6 \pm 6.9 \\
(n=2)\end{array}$ & $\begin{array}{c}220 \\
(n=1)\end{array}$ \\
\hline$>18 \mathrm{~d}$ & $\begin{array}{l}5.4 \pm 1.2 \\
(n=3)\end{array}$ & $\begin{array}{c}>100,000 \\
(n=3)\end{array}$ & $\begin{array}{c}15 \pm 1.5 \\
(n=3)\end{array}$ & $\begin{array}{l}4.0 \pm 3.9 \\
(n=3)\end{array}$ \\
\hline
\end{tabular}

Values are means \pm SEM. NA, not available.

In myometrium obtained from nulliparous sheep, the $\mathrm{AT}_{1}$ receptor antagonist Losartan had minimal evidence of inhibition of [ $\left.{ }^{125} \mathrm{I}\right]$-ANG II binding, whereas the $\mathrm{AT}_{2}$ antagonist PD123177 resulted in substantial displacement (Table I). Thus, it was estimated that the $\mathrm{AT}_{2}$ receptors accounted for $\sim 85 \%$ of total receptor binding. During the last third of ovine pregnancy, there was a reversal of myometrial receptor subtype predominance. This was evidenced by the observation that the $\mathrm{AT}_{1}$ receptor antagonist Losartan (Fig. $5 A$, Table I) now caused substantial displacement of [ $\left.{ }^{125} \mathrm{I}\right]$-ANG II binding and accounted for $\sim 80 \%$ of the receptor population. In contrast, the $\mathrm{AT}_{2}$ receptor antagonists $\mathrm{PD} 123177$ and CGP42112A resulted in minimal displacement. Soon after parturition, i.e., $\leq 2 \mathrm{wk}$, the displacement of [ $\left.{ }^{125} \mathrm{I}\right]-\mathrm{ANG}$ II by $\mathrm{AT}_{1}$ and $\mathrm{AT}_{2}$ receptor antagonists was nearly equivalent, accounting for $\sim 40 \%$ and $\sim 60 \%$, respectively, of the receptors present (Fig. $5 \mathrm{~B}$, Table I). After the 18th day postpartum (Fig. $5 \mathrm{C}$, Table I), the pattern of binding inhibition had reversed, again mirroring that seen in myometrium from nulliparous animals. The $\mathrm{AT}_{2}$ receptor antagonists again displaced $\sim 85 \%$ of $\left[{ }^{125} \mathrm{I}\right]-$ ANG II binding versus 15\% for Losartan.

To demonstrate that the $15-20 \%$ of total receptor binding sites resistant to either Losartan or PD123177 and CGP42112A in myometrium from pregnant, late postpartum, and nulliparous sheep was a subpopulation of the alternate receptor subtype, we blocked the predominant $\mathrm{AT}_{1}$ or $\mathrm{AT}_{2}$ receptor subtype in plasma membrane preparations of myometrium obtained from nulliparous $(n=2)$, pregnant $(n=2 ; 127-139 \mathrm{~d}$ of gestation), and postpartum ( $n=3 ; 31$ to $>38 \mathrm{~d}$ after delivery) ewes by preincubation with Losartan or either PD123177 or CGP42112A, respectively. We were then able to demonstrate [ ${ }^{125}$ I]-ANG II displacement by the alternative receptor subtype-specific antagonist when the $\mathrm{IC}_{50}$ in the absence of blocking exceeded 100,000 $\mathrm{nM}$ (Fig. 6). Thus, we estimated that $\mathrm{AT}_{2}$ and $\mathrm{AT}_{1}$ receptor subtypes represented $20 \%$ and $15 \%$ of the total myometrial $\mathrm{AT}$ receptor population for pregnant and late postpartum/nulliparous myometrium, respectively.
Force generation studies. ANG II caused a significant concentration-dependent increase in force generation by myometrial strips obtained from pregnant ewes $(P<0.001)$, values increasing from $0.08 \pm 0.18 \times 10^{4} \mathrm{dyn} / 10 \mathrm{~min}$ with $10^{-11} \mathrm{M}$ ANG II to $5.1 \pm 0.9 \times 10^{4} \mathrm{dyn} / 10 \mathrm{~min}$ with $10^{-6} \mathrm{M}$ ANG II (Fig. $9 \mathrm{~A}$ ). In contrast, there was only a modest rise in force generated in myometrial strips from postpartum ewes at $10^{-7}$ and $10^{-6}(P=0.002)$. Furthermore, the responses in strips from pregnant and postpartum ewes differed significantly at all
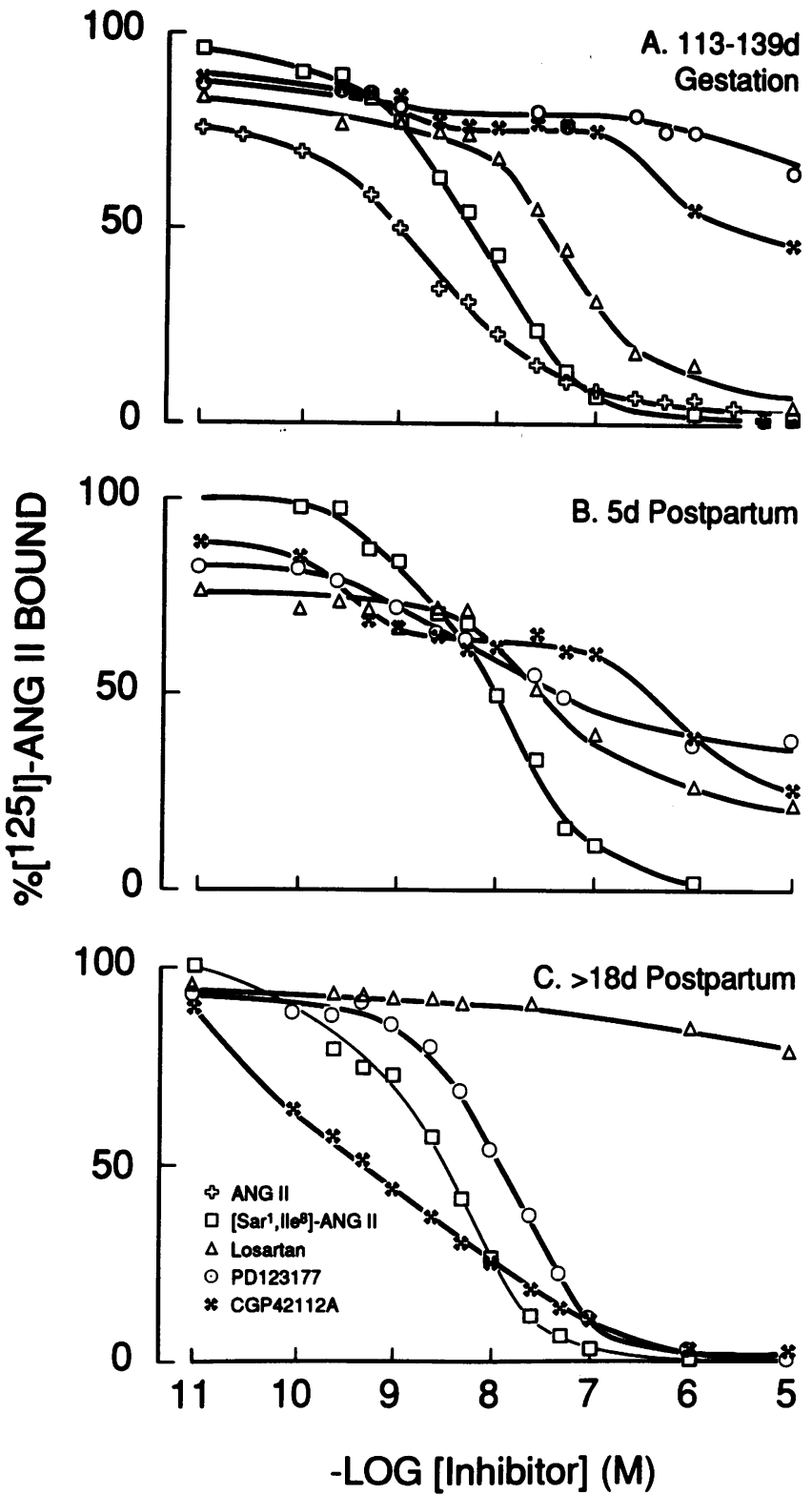

Figure 5. Displacement curves for inhibitors of [ $\left.{ }^{125} \mathrm{I}\right]$-ANG II binding to plasma membrane fractions prepared from ovine myometrium obtained at $(A)$ 113-139 d of gestation (values are means of more than five experiments with each antagonist, except ANG II which represents a mean of two experiments, each performed in duplicate); $(B) 5 \mathrm{~d}$ postpartum (values are means of two experiments with each antagonist, except CGP42112A $(n=1)$, each performed in duplicate); and $(C) \geq 18 \mathrm{~d}$ postpartum (values are means of three experiments with each antagonist, each performed in duplicate). Sar represents [ $\left.\mathrm{Sar}^{1}, \mathrm{Ile}^{8}\right]$-ANG II. The $y$-axis represents the percent of specifically bound [ $\left.{ }^{125} \mathrm{I}\right]-\mathrm{ANG} \mathrm{II}$. 


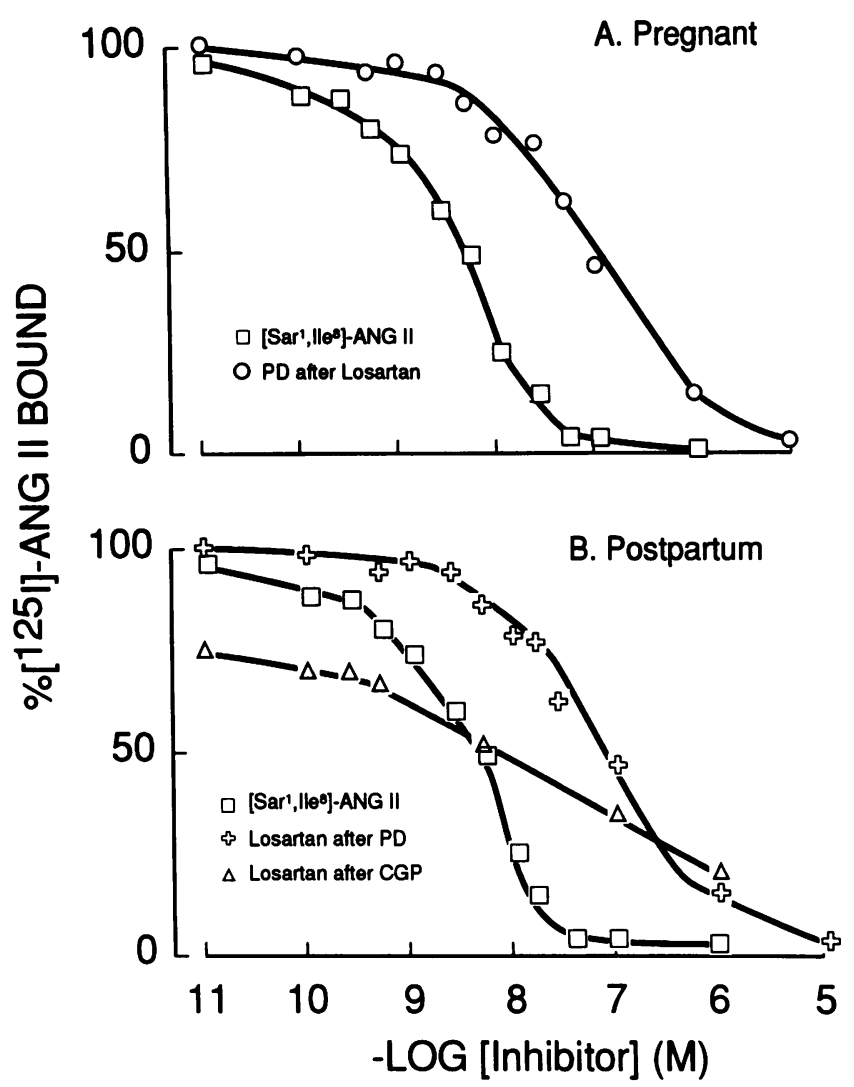

Figure 6. Displacement curves for inhibitors of [ $\left.{ }^{125} \mathrm{I}\right]$-ANG II binding to ovine myometrial plasma membrane fractions: $(A) 134-139 \mathrm{~d}$ of gestation, displacement by PD123177 (PD) after preincubation with $10^{-6} \mathrm{M}$ Losartan; values are means of two experiments performed in duplicate. $(B)>30 \mathrm{~d}$ postpartum, displacement by Losartan after preincubation with $10^{-6} \mathrm{M}$ PD123177 or CGP42112A (CGP); values represent three experiments performed in duplicate.

doses $\geq 10^{-9} \mathrm{M}$ ANG II $(P<0.05)$. To determine if the $\mathrm{AT}_{1}$ subtype was responsible for the ANG II-induced contraction, we added $10^{-6} \mathrm{M}$ Losartan to the bath of myometrial strips from pregnant and postpartum ewes 2 min before addition of $10^{-7} \mathrm{M}$ ANG II. This decreased ANG II-induced contractile responses in myometrium from pregnant and postpartum ewes by $43 \%$ and $65 \%$, respectively. The addition of $10^{-5} \mathrm{M}$ Losartan inhibited ANG II-induced contractile responses in strips from early and late postpartum animals $93 \%$ and $91 \%$, respectively. To determine if the increased density of $\mathrm{AT}_{2}$ subtype in myometrium from postpartum sheep might contribute to the diminished contractile response to ANG II seen in these tissues, we examined responses in the presence and absence of an $\mathrm{AT}_{2}$ antagonist. The addition of $10^{-7} \mathrm{M}$ PD123177 to the baths of myometrial strips from early and late postpartum ewes 4 min before the addition of $10^{-7} \mathrm{M}$ ANG II had no effect on the ANG II-induced contractile responses.

We recently observed that myometrial strips from late postpartum ewes generate significantly less stress to a variety of agonists than those from pregnant animals (33). To test the hypothesis that the small contractile responses to ANG II by strips from postpartum ewes resulted from a nonspecific depression in stress-generating capacity, we compared the integrated force responses to ANG II to those in response to a mixture of stimulating agents that elicits maximal force. As seen in Fig. $7 B$, the curve depicting the normalized responses for myometrium from postpartum ewes lies below that for strips from pregnant animals. Whereas normalized responses of myometrium from pregnant ewes remained dose-dependent $(P<0.001)$, ANG II had no significant effect on the normalized responses in myometrial strips from postpartum sheep $(P$ $=0.264)$. When we compared the normalized maximum responses, ANG II resulted in less force in strips from postpartum vs. pregnant sheep, $0.33 \pm 0.04$ vs. $0.55 \pm 0.07(P<0.05)$, respectively.

\section{Discussion}

Regulation of smooth muscle AT receptor binding has not been thoroughly studied during pregnancy, and apparent contradictions exist in the literature. For example, downregulation of smooth muscle AT receptors has been observed during pregnancy in rabbit mesenteric arteries (36) and myometrium from the rat (25) and sheep (24), whereas binding density and affinity of the AT receptor in bladder smooth muscle from pregnant rats (8) and arteries from several vascular beds in pregnant sheep (12) or rats (23) are unchanged. These inconsistencies suggest that $\mathrm{AT}$ receptor regulation during pregnancy may differ among various types of smooth muscle or that reported differences in receptor regulation reflect species specificity. We performed binding studies in tissues obtained from nulliparous, gravid, and postpartum ewes, comparing for the first time the binding characteristics of the AT receptor in both vascular and nonvascular smooth muscle, i.e., myometrium. We have demonstrated that AT receptor regulation differs in these two smooth muscles during pregnancy, and that this difference primarily reflects a decrease in expression of the myometrial $\mathrm{AT}_{2}$ receptor subtype during pregnancy.

In nonpregnant adult animals the binding density of vascular and nonvascular (e.g., bladder and myometrium) smooth muscle AT receptors is similarly affected by increases in circulating levels of ANG II (14-20), yielding decreases in $B_{\max }$ without alterations in affinity. Similar changes in binding density have been assumed to occur during pregnancy because of the elevated levels of ANG II normally found (1); however, AT receptor binding characteristics in vascular and nonvascular
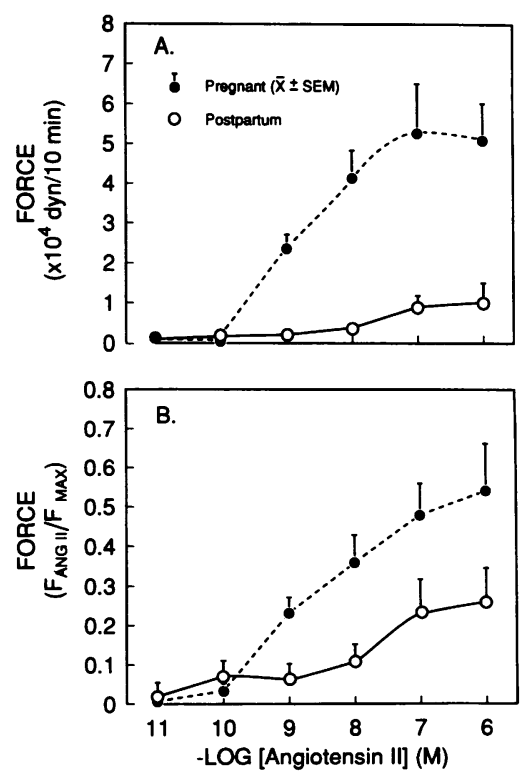

Figure 7. Force generation by myometrial strips in response to ANG II. Protocols for application of ANG II and analysis of force responses are described in Methods. $(A)$ Integrated force responses to ANG II; values represent mean \pm SEM of responses calculated as the differences in contractile activity before and after exposure to ANG II $(n=3-7)$. (B) Force responses normalized to maximal force elicited by a mixture of agents $(n=3-5)$. 
smooth muscle have not been compared. We studied AT receptor regulation in sheep since plasma ANG II levels increase fourfold in pregnancy (11-13), and vascular AT receptor binding is modified by salt depletion (6) or administration of converting enzyme inhibitors (37). In the present study total myometrial AT receptor binding capacity decreased $>90 \%$ during the last third of ovine gestation and increased progressively after parturition, subsequently attaining values seen in tissues from nulliparous animals. Siddiqi et al. (24) also observed downregulation, but only compared "nonpregnant" with pregnant animals. The myometrial AT receptor, therefore, may be responsive to changes in plasma ANG II. In contrast, AT receptor binding density in aortic smooth muscle was unchanged during pregnancy, confirming recent observations in the ewe (12) and rat (23). Thus, in contrast to nonpregnant animals, AT receptor regulation in these two tissues differs during ovine pregnancy. Furthermore, these data and those from the gravid rat $(8,25)$ clearly demonstrate that alterations in AT receptor binding in nonvascular smooth muscle during pregnancy do not necessarily reflect similar alterations in vascular smooth muscle.

While we were unable to determine the precise time in pregnancy when the density of myometrial AT receptors decreases, it must occur during the first two-thirds of gestation, during which time dramatic changes take place in the endocrine milieu, placentation, and uterine growth (38). The decrease in $B_{\max }$, however, is unlikely to reflect only uterine growth, since an additional twofold increase in myometrial mass occurs during the study period (38) and receptor density remains unchanged over that time (Fig. 3). Alternatively, changes in the endocrine milieu might account for the alterations in receptor binding. Placental estrogen and progesterone production is quite high (39) and both have been reported to affect AT receptor density. Estrogen upregulates or maintains AT receptor density in rat myometrium (26) and placenta (40) despite increases in plasma ANG II, while progesterone downregulates and/or inhibits the estrogenic effects $(26,40)$. Mineralocorticoids also are elevated in pregnancy $(1,41)$ and appear to upregulate the vascular AT receptor despite elevated circulating levels of ANG II $(42,43)$. These effects have not been extensively studied in pregnancy. Furthermore, it is unclear why the vascular and myometrial receptors do not change in parallel as seen in nonpregnant adult animals (16-19). This may reflect tissue specific regulatory mechanisms or differences in exposure to these hormones. For example, estrogen is rapidly sulfoconjugated by the ovine placenta, thus little active hormone reaches the peripheral circulation (44). Furthermore, progesterone production predominates until parturition (39). Thus, peripheral vascular tissues may be exposed to relatively low plasma levels of either steroid as compared to mineralocorticoids, whereas the myometrium is exposed predominantly to locally produced progesterone, causing receptor downregulation or inhibition of the estrogenic effects. This and the role of mineralocorticoids require additional study.

We studied myometrium from nulliparous and postpartum ewes, representing two distinct nonpregnant states. Since total myometrial AT receptor binding density dramatically fell during pregnancy and increased during the puerperium, attaining values seen in nulliparous myometrium by $4 \mathrm{wk}$, we wondered if this reflected a change in receptor subtype. At least two AT receptor subtypes have been identified $(45,46)$. The $A T_{1}$ receptor is dithiothreitol sensitive and mediates smooth muscle contraction through calcium mobilization and hydrolysis of inositol phospholipids (45, 47-49). The $\mathrm{AT}_{2}$ receptor is insensitive to dithiothreitol, and its second messenger as well as its function are unclear. Our observation of a predominance of $\mathrm{AT}_{2}$ receptors in myometrium from nulliparous and postpartum ewes is consistent with observations in myometrium from nonpregnant women and primates $(35,45)$, but differs from the heterogeneous populations in the nonpregnant rat and rabbit uterus $(46,50)$. Our finding of predominantly $\mathrm{AT}_{1}$ receptors in myometrium during pregnancy and the gradual reappearance of $\mathrm{AT}_{2}$ receptors after parturition is novel. Furthermore, this is a reversible phenomenon associated with pregnancy. It is notable that the fall in total myometrial AT receptor binding density in pregnancy primarily reflects a decrease in $\mathrm{AT}_{2}$ receptor expression, which may explain the fall in $B_{\max }$ reported in the gravid rat uterus (25). It, however, does not explain the rise in affinity during the final $2 \mathrm{wk}$ of gestation, an observation that may deserve further investigation.

A change in AT receptor subtype also occurs during fetal and neonatal development $(51,52)$. Within $72 \mathrm{~h}$ after delivery the $\mathrm{AT}_{2}$ receptor is no longer expressed in several tissues of the neonatal rat (51). Reciprocal changes also occur in aortic smooth muscle between birth and one month of age (52), i.e., the density of $\mathrm{AT}_{2}$ receptor falls as that of $\mathrm{AT}_{1}$ rises. The uniqueness of our observations is that we have described for the first time a reversible change in subtype expression in an adult mammal that is associated with a normal physiologic event, namely pregnancy. Furthermore, whereas the predominant maternal myometrial receptor subtype is $\mathrm{AT}_{1}$ during pregnancy, in fetal-neonatal studies $\mathrm{AT}_{2}$ was predominant in mesenchymal and vascular tissues in the fetus. These differences may reflect different pregnancy-related factors influencing fetal and maternal tissues, or alternatively, tissue specific responses to a common factor, which is no longer present after parturition.

Although total myometrial AT receptor density decreases $>90 \%$ during pregnancy and increases following parturition, this does not accurately characterize the changes in density of each receptor subtype. In nulliparous animals the myometrial $\mathrm{AT}_{1}$ receptor accounts for $\sim 15 \%$ of binding versus $\sim 80 \%$ in tissues from pregnant ewes (Fig. $8 \mathrm{~A}$ ). Thus, the estimated density of myometrial $\mathrm{AT}_{1}$ receptors is $223 \pm 25$ and $110 \pm 13$ $\mathrm{fmol} / \mathrm{mg}$ of protein (Fig. $8 \mathrm{~B}$ ), respectively, demonstrating a $51 \%$ fall in binding density in pregnancy $(P \leq 0.001)$. The decrease in $\mathrm{AT}_{2}$ receptor binding density is substantially greater, reaching $98 \%$. After parturition the relative amount of $\mathrm{AT}_{2}$ receptor binding increases at 2 wk to $\sim 60 \%$ as compared to a decrease to $\sim 40 \%$ for $\mathrm{AT}_{1}$ receptors (Fig. $8 \mathrm{~A}$ ). It is notable that there is no change in $\mathrm{AT}_{1}$ receptor density, but a fivefold increase $\mathrm{AT}_{2}$ receptor density (Fig. $8 \mathrm{~B}$ ). Thus, the upregulation of these two receptors occurs at different times after delivery. Beyond 4 wk postpartum the density of myometrial $\mathrm{AT}_{1}$ and $\mathrm{AT}_{2}$ receptors does not differ from that in tissues from nulliparous animals. Therefore, although there is evidence of downregulation of both receptor subtypes in ovine pregnancy, the magnitude is markedly different and the fall in $\mathrm{AT}_{2}$ receptor binding primarily accounts for the decrease in total AT receptor binding observed by us and others (24). What regulates the specific expression of these receptor subtypes remains to be determined.

Since $\mathrm{AT}_{1}$ receptor density fell $50 \%$ during pregnancy and remained depressed throughout the last third of gestation, one 

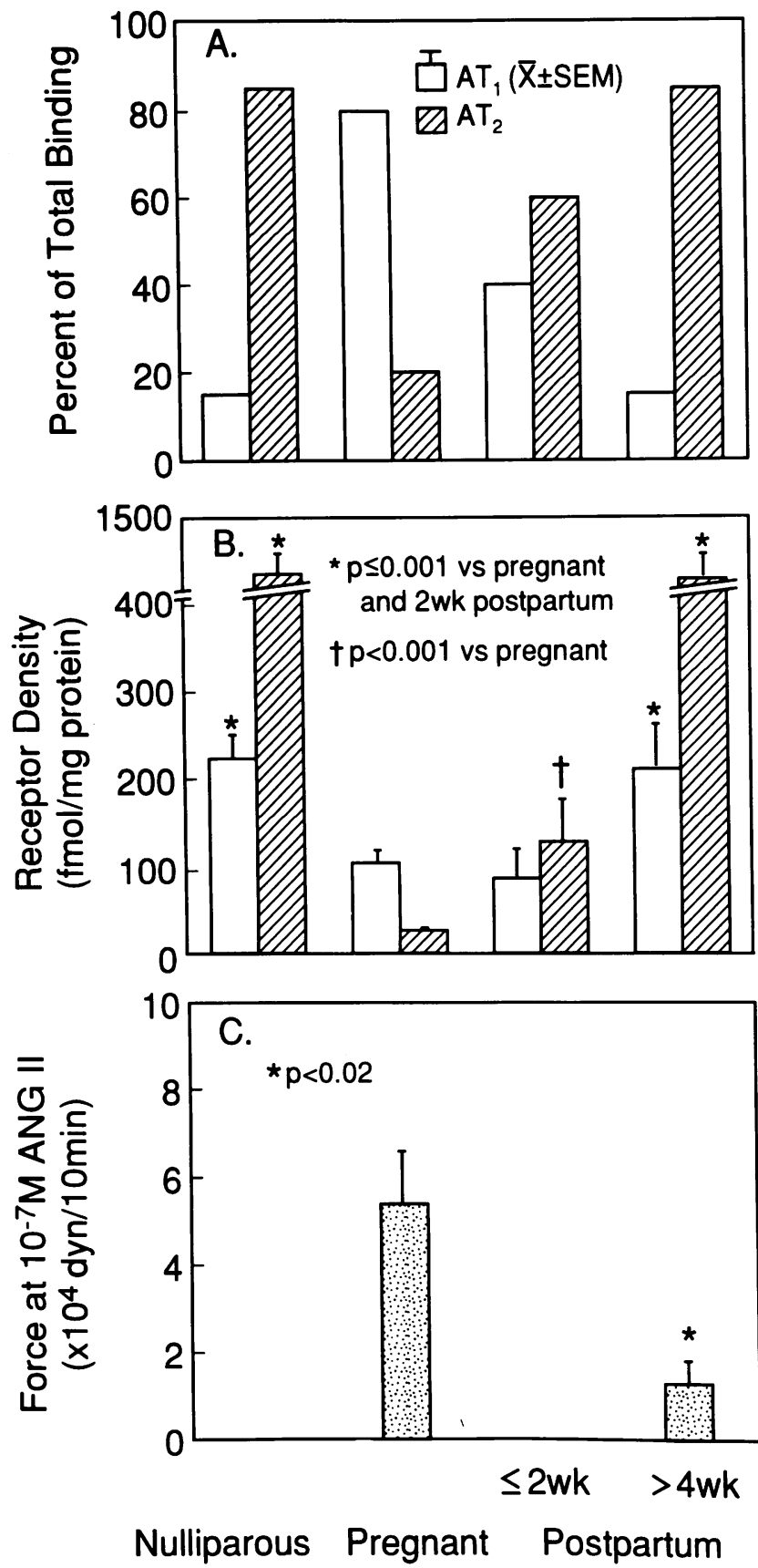

Figure 8. Comparison of the relative $(A)$ and absolute $(B)$ density of AT receptor subtypes and ANG II-induced force generation $(C)$ in myometrium prior to and during ovine pregnancy and the puerperium.

might have expected a decrease in myometrial contractility in response to ANG II during pregnancy. In contrast, $\mathrm{AT}_{1}$-mediated increases in force by myometrial strips were greater in myometrium from pregnant versus postpartum animals, in whom the $\mathrm{AT}_{1}$ receptor was upregulated. It is possible that the 14-fold rise in $\mathrm{AT}_{2}$ receptor density and the depressed contractile responses to ANG II in the puerperium (Fig. $8 C$ ) might be causal. First, $\mathrm{AT}_{2}$ receptors may act by preferentially binding ANG II; however, since the $K_{\mathrm{d}}$ is similar for both receptor subtypes, this is unlikely. There also are no data to suggest that $\mathrm{AT}_{2}$ receptors act as "clearance" receptors. Second, $\mathrm{AT}_{2}$ receptors may exert an inhibitory effect on $\mathrm{AT}_{1}$ function. We ob- served that ANG II-induced force generation was $\mathrm{AT}_{1}$ receptor mediated, consistent with observations in rabbit myometrium (47), and that this was unaffected by an $\mathrm{AT}_{2}$ antagonist. Bottari et al. (53) examined $\mathrm{AT}_{2}$ receptor function in rat adrenal glomerular and $\mathrm{PC} 12 \mathrm{~W}$ cells. They suggested that effects mediated through the $\mathrm{AT}_{2}$ receptor reflect inhibition of particulate guanylate cyclase stimulation via enhanced phosphotyrosine phosphatase activity. This should have resulted in greater contractile forces in postpartum myometrium and attenuation of these responses in the presence of an $\mathrm{AT}_{2}$ receptor antagonist. Our studies, however, clearly demonstrate markedly reduced contractile responses in $\mathrm{AT}_{2}$ receptor abundant myometrium from postpartum ewes as compared to $\mathrm{AT}_{1}$ predominance in pregnancy. Moreover, responses were not attenuated after adding an $\mathrm{AT}_{2}$ antagonist. Thus, the diminished contractile response to ANG II is not mediated via the $\mathrm{AT}_{2}$ receptor, but rather may reflect altered coupling with second messenger pathways that regulate the contractile proteins or changes in the contractile proteins themselves $(33,54)$. Alternatively, this change in $\mathrm{AT}_{2}$ receptor expression may relate to the uterine remodeling that occurs during pregnancy and again after parturition. This has not been examined to the best of our knowledge.

In the present study we have demonstrated differential regulation of total AT receptor binding in vascular and uterine smooth muscle during ovine pregnancy. We have confirmed our prior observations (12) that the vascular AT receptor is not downregulated during ovine pregnancy; therefore, this cannot account for the attenuated pressor responses normally seen in pregnancy $(5)$, a conclusion consistent with others $(12,23)$. Importantly, we have demonstrated that the decrease in total myometrial AT receptor $B_{\max }$ seen in pregnant sheep primarily reflects a decrease in expression of $\mathrm{AT}_{2}$ receptors and that this is reversed soon after parturition. Finally, although there is an association between the increase in $\mathrm{AT}_{2}$ receptor expression and attenuation of $\mathrm{AT}_{1}$ receptor-mediated contractile responses, we were unable to demonstrate a mechanism for this. Thus, it remains to be determined what factor(s) regulate the expression of myometrial $\mathrm{AT}_{2}$ receptors and what role this receptor plays in myometrial remodeling and/or function during pregnancy and the puerperium.

\section{Acknowledgments}

We would like to thank Mr. Kevin Horning and Mr. David Durham for their skilled technical assistance, Dr. Marc de Gasparo, Ciba-Geigy Ltd., for CGP42112A, Dr. Ronald D. Smith, E.I. du Pont de Nemours \& Co., for Losartan, Parke-Davis Pharmaceutical Research Division for PD123117, and Mrs. Susan Battle-Brown for her assistance in the preparation of the manuscript.

This work was supported by grants HD08783 and HL32607 from the National Institutes of Health.

\section{References}

1. Wilson, M., A. A. Morganti, I. Zevoudakis, R. L. Letcher, B. M. Romney, P. Von Oeyon, S. Papera, J. E. Sealey, and J. H. Laragh. 1980. Blood pressure, the reninaldosterone system and sex steroids throughout normal pregnancy. Am.J. Med. 68:97-104.

2. Chesley, L. C., O. E. Talledo, C. S. Bohler, and F. P. Zuspan. 1965. Vascular reactivity to angiotensin II and norepinephrine in pregnant and nonpregnant women. Am. J. Obstet. Gynecol. 91:837-842.

3. Talledo, O. E. 1966. Renin-angiotensin system in normal and toxemic pregnancies. I. Angiotensin infusion test. Am. J. Obstet. Gynecol. 96:141-143.

4. Gant, Jr., N. F., G. L. Daley, S. Chand, P. J. Whalley, and P. C. MacDon- 
ald. 1973. A study of angiotensin II pressor responses throughout primigravid pregnancy. J. Clin. Invest. 52:2682-2689.

5. Rosenfeld, C. R., and N. F. Gant, Jr. 1981. The chronically instrumented ewe. A model for studying vascular reactivity to angiotensin II in pregnancy. $J$. Clin. Invest. 67:486-492.

6. Blair-West, J. R., J. P. Coghlan, D. A. Denton, B. A. Scoggins, and E. M. Wintour. 1972. The pressor effect of angiotensin II in pregnant sheep. Aust. J. Exp. Biol. Med. Sci. 50:739-744.

7. Donker, A. J. M., I. Min, and R. C. Venuto. 1983. The conscious instrumented rabbit: a model for the study of mechanisms of blood pressure regulation during pregnancy. Hypertension 5:514-520.

8. Paller, M. S. 1984. Mechanism of decreased pressor responsiveness to ANG II, NE, and vasopressin in pregnant rats. Am. J. Physiol. 247:H100-H108.

9. Rosenfeld, C. R. 1977. Distribution of cardiac output in ovine pregnancy. Am. J. Physiol. 232:H231-H235.

10. Naden, R. P., N. F. Gant, Jr., and C. R. Rosenfeld. 1984. The pressor response to angiotensin II: the roles of peripheral and cardiac responses in pregnant and nonpregnant sheep. Am. J. Obstet. Gynecol. 148:450-457.

11. Matsuura, S., R. P. Naden, N. F. Gant, Jr., C. R. Parker, Jr., and C. R. Rosenfeld. 1981. Effect of volume expansion on the pressor response to angiotensin II in pregnant ewes. Am. J. Physiol. 240:H908-913.

12. Mackanjee, H. R., P. W. Shaul, R. R. Magness, and C. R. Rosenfeld. 1991. Angiotensin II vascular smooth muscle receptors are not down-regulated in nearterm pregnant sheep. Am. J. Obstet. Gynecol. 165:1641-1648.

13. Naden, R. P., S. Coultrup, B. S. Arant, Jr., and C. R. Rosenfeld. 1985. Metabolic clearance of angiotensin II in pregnant and nonpregnant sheep. Am. J. Physiol. 249:E49-E55.

14. Aguilera, G., and K. J. Catt. 1981. Regulation of vascular angiotensin II receptors in the rat during altered sodium intake. Circ. Res. 49:751-758.

15. Gunther, S., M. A. Gimbrone, Jr., and R. W. Alexander. 1980. Regulation by angiotensin II of its receptors in resistance blood vessels. Nature (Lond.). 287:230-232.

16. Catt, K. J., F. A. C. Mendelsohn, M. A. Millan, and G. Aguilera. 1984 The role of angiotensin II receptors in vascular regulation. J. Cardiovasc. Pharmacol. 6:S575-S586.

17. Devynck, M. A., and P. Meyer. 1976. Angiotensin receptors in vascular tissue. Am. J. Med. 61:758-767.

18. Devynck, M. A., B. Rouzaire-Dubois, E. Chevillotte, and P. Meyer. 1976 Variations in the number of uterine angiotensin II receptors following changes in plasma angiotensin levels. Eur. J: Pharmacol. 40:27-37.

19. Devynck, M. A., M. G. Pernollet, G. J. MacDonald, P. G. Matthews, R. S Raisman, and P. Meyer. 1978. Alterations of adrenal and uterine angiotensin II receptors during variation of sodium intake and/or experimental hypertension. Clin. Sci. Mol. Med. 55:171s-174s.

20. Aguilera, G., R. L. Hauger, and K. J. Catt. 1978. Control of aldosterone secretion during sodium restriction: adrenal receptor regulation and increased adrenal sensitivity to angiotensin II. Proc. Natl. Acad. Sci. USA. 75:975-979.

21. Gant, Jr., N. F., S. Chand, P. J. Whalley, and P. C. MacDonald. 1974. The nature of pressor responsiveness to angiotensin II in human pregnancy. Obstet. Gynecol. 43:854-860.

22. Cunningham, F. G., K. Cox, and N. F. Gant, Jr. 1975. Further observations on the nature of pressor responsitivity to angiotensin II in human pregnancy. Obstet. Gynecol. 46:581-583.

23. Parent, A., E. L. Schiffrin, and J. St-Louis. 1991. Receptors for Arg $^{8}$-vasopressin, angiotensin II, and atrial natriuretic peptide in the mesenteric vasculature of pregnant rats. Can. J. Physiol. 69:137-144.

24. Siddiqi, T. A., B. B. Koenig, and K. E. Clark. 1986. Pregnancy causes a decrease in the number and affinity of myometrial angiotensin II receptors. $O b$ stet. Gynecol. 68:820-824.

25. Schirar, A., A. Capponi, and K. J. Catt. 1980. Elevation of uterine angiotensin II receptors during early pregnancy in the rat. Endocrinology. 106:15211527.

26. Schirar, A., A. Capponi, and K. J. Catt. 1980. Regulation of uterine angiotensin II receptors by estrogen and progesterone. Endocrinology. 106:5-12.

27. Rosenfeld, C. R., A. P. Killam, F. C. Battaglia, E. L. Makowski, and G. Meschia. 1973. Effect of estradiol-17, $\beta$ on the magnitude and distribution of uterine blood flow in nonpregnant, oophorectomized ewes. Pediatr. Res. 7:139148.

28. Lowry, O. H., N. J. Rosebrough, A. L. Farr, and R. J. Randall. 1951. Protein measurement with the folin phenol reagent. J. Biol. Chem. 193:265-275.

29. Munson, P. J., and D. Rodbard. 1980. LIGAND: a versatile computerized approach for the characterization of ligand-binding systems. Anal. Biochem. 107:220-239.

30. McPherson, G. A. 1985. Analysis of radioligand binding experiments: a collection of computer programs for the IBM PC. J. Pharmacol. Methods. 14:213-228.

31. Herblin, W. F., A. T. Chiu, D. E., McCall, R. J. Ardecky, D. J. Carini, J. V.
Duncia, L. J. Pease, P. C. Wong, R. R. Wexler, A. L. Johnson, et al. 1991 Angiotensin II receptor heterogeneity. Am. J. Hypertens. 4:299s-302s.

32. Obermuller, N., T. Unger, J. Culman, P. Gohlke, M. de Gasparo, and S. P.

Bottari. 1991. Distribution of angiotensin II receptor subtypes in rat brain nuclei. Neurosci. Lett. 132:11-15.

33. Ipson, M., C. R. Rosenfeld, and K. E. Kamm. 1992. Alterations in stress and actin-myosin contents in ovine myometrium during pregnancy. In Proceedings of the Annual Meeting of the Society for Gynecologic Investigation, San Antonio, TX. Abstr. 79, page 148

34. Bennett, Jr., J. P. 1978. Methods in binding studies. In Neurotransmitter Receptor Binding. H. I. Yamamura, S. J. Enna, and M. J. Kuhar, editors. Raven Press, New York. 57-90.

35. Criscione, L., H. Thomann, S. Whitebread, M. de Gasparo, P. Bühlmayer, P. Herold, F. Ostermayer, and B. Kamber. 1990. Binding characteristics and vascular effects of various angiotensin II antagonists. J. Cardiovasc. Pharmacol. 16:S56-S59.

36. Brown, G. P., and R. C. Venuto. 1986. Angiotensin II receptor alterations during pregnancy in rabbits. Am. J. Physiol. 251:E58-E64.

37. Siddiqi, T. A., J. E. Austin, J. C. Holroyd, and K. E. Clark. 1983. Modulation of angiotensin II pressor responsiveness by circulating levels of angiotensin II in pregnant sheep. Am. J. Obstet. Gynecol. 145:458-464.

38. Rosenfeld, C. R. 1989. The Uterine Circulation. Perinatology Press, Ithaca, NY. 312 pp.

39. Liggins, G. C., R. J. Fairclough, S. A. Grieves, C. S. Forster, and B. S. Knox. 1977. Parturition in the sheep. In The Fetus and Birth. Ciba Found. Symp. 47:5-25.

40. Kurauchi, O., S. Mizutani, S. Nomura, M. Furuhashi, M. Kasugai, and Y. Tomoda. 1989. Changes in the binding of angiotensin II to rat placental receptors by estrogen and progesterone. Horm. Metab. Res. 21:558-560.

41. Parker, Jr., C. R., R. B. Everett, P. J. Whalley, J. G. Quirk, Jr., N. F. Gant, Jr., and P. C. MacDonald. 1980. Hormone production during pregnancy in the primigravid patient. II. Plasma levels of deoxycorticosterone throughout pregnancy of normal women and women who developed pregnancy-induced hypertension. Am. J. Obstet. Gynecol. 138:626-631.

42. Schiffrin, E. L., J. Gutkowska, and J. Genest. 1984. Effect of angiotensin II and deoxycorticosterone infusion on vascular angiotensin II receptors in rats. Am. J. Physiol. 246:H608-H614.

43. Schiffrin, E. J., D. J. Franks, and J. Gutkowska. 1985. Effect of aldosterone on vascular angiotensin II receptors in the rat. Can. J. Physiol. Pharmacol. 63:1522-1527.

44. Rosenfeld, C. R., R. J. Worley, L. Milewich, N. F. Gant, Jr., and C. R Parker, Jr. 1980. Ovine fetoplacental sulfoconjugation and aromatization of dehydroepiandrosterone. Endocrinology. 106:1971-1979.

45. Whitebread, S., M. Mele, B. Kamber, and M. de Gasparo. 1989. Preliminary biochemical characterization of two angiotensin II receptor subtypes. Bio chem. Biophys. Res. Commun. 163:284-291.

46. Chiu, A. T., W. F. Herblin, D. E. McCall, R. J. Ardecky, D. J. Carini, J. V. Duncia, L. J. Pease, P. C. Wong, R. R. Wexler, A. L. Johnson, and et al. 1989. Identification of angiotensin II receptor subtypes. Biochem. Biophys. Res. Commun. 165:196-203.

47. Dudley, D. T., R. L. Panek, T. C. Major, G. H. Lu, R. F. Bruns, B. A Klinkefus, J. C. Hodges, and R. E. Weishaar. 1990. Subclasses of angiotensin II binding sites and their functional significance. Mol. Pharmacol. 38:370-377.

48. Chiu, A. T., D. E. McCall, T. T. Nguyen, D. J. Carini, J. V. Duncia, W. F Herblin, R. T. Uyeda, P. C. Wong, R. R. Wexler, A. L. Johnson, and et al. 1989. Discrimination of angiotensin II receptor subtypes by dithiothreitol. Eur. J. Pharmacol. 170:117-118.

49. Chiu, A. T., D. E. McCall, R. J. Ardecky, J. V. Duncia, T. T. Nguyen, and P. B. M. W. M. Timmermans. 1990. Angiotensin II receptor subtypes and their selective nonpeptide ligands. In Receptor. G. Litwack, editor. The Humana Press, Totowa, NJ. 33-40.

50. de Gasparo, M., S. Whitebread, M. Mele, A. S. Montani, P. J. Whitcombe H. P. Ramjoué, and B. Kamber. 1990. Biochemical characterization of two angiotensin II receptor subtypes in the rat. J. Cardiovsc. Pharmacol. 16:S31-S35.

51. Grady, E. F., L. A. Sechi, C. A. Griffin, M. Schambelan, and J. E. Kalinyak. 1991. Expression of $\mathrm{AT}_{2}$ receptors in the developing rat fetus. J. Clin. Invest. 88:921-933.

52. Viswanathan, M., K. Tsutsumi, F. M. A. Correa, and J. M. Saavedra. 1991. Changes in expression of angiotensin receptor subtypes in the rat aorta during development. Biochem. Biophys. Res. Commun. 179:1351-1357.

53. Bottari, S. P., I. N. King, S. Reichlin, I. Dahlstroem, N. Lydon, and M. de Gasparo. 1992. The angiotensin II receptor stimulates protein tyrosine phosphatase activity and mediates inhibition of particulate guanylate cyclase. Biochem. Biophys. Res. Commun. 183:206-211.

54. Rosenfeld, C. R., and K. E. Kamm. Myosin heavy chain isoforms are regulated differently in myometrium and uterine artery smooth muscle in ovine pregnancy and the puerperium. 1993. Biophys. J. 64:A34. (Abstr. M-POS65) 